\title{
CHOLESTEROL CONCENTRATION AND CHOLESTEROL SYNTHESIS IN AORTAS OF RATS WITH RENAL HYPERTENSION *
}

\author{
By M. M. DALY, $\dagger$ Q. B. DEMING, V. M. RAEFF, ANd L. M. BRUN \\ (From the Departments of Biochemistry and Medicine, and the Unit for Research in Aging, \\ Albert Einstein College of Medicine, Yeshiva University, and from the Columbia \\ University Research Service, Goldwater Memorial Hospital, and the \\ Departments of Medicine and Biochemistry, College of Physicians \\ $\mathcal{E}$ Surgeons, Columbia University, New York, N. Y.)
}

(Submitted for publication March 20, 1963; accepted June 20, 1963)

Hypertension has been shown to increase the severity of atherosclerosis in both man and experimental animals (1). Most observers attribute this effect of hypertension to local damage to the vessels produced by the augmented pressure or turbulence of the blood. This concept is supported by the more frequent occurrence and greater severity of atherosclerotic lesions at locations of high pressure or turbulence. It has also been suggested that high blood pressure increases the filtration of blood across arterial walls and, presumably, affords an opportunity for retention of lipid in the walls (2).

The present report is concerned with two other factors that may affect the concentration of lipid in the aortas of hypertensive rats: the concentration of lipid in the blood, and lipid synthesis in the aorta itself. Cholesterol concentrations were found to be significantly higher in aortas of hypertensive rats than in those of normotensive controls. This difference was observed when hypertensive animals had higher serum cholesterol levels than their controls, but the difference persisted when experimental conditions were adjusted so that the serum cholesterol levels were comparable in the two groups of animals. It was found that the rate of cholesterol synthesis in vitro is increased in the aortas of hypertensive rats.

* Work supported in part by U. S. Public Health Service grants H-3622, H-5143, H-3838, M-2562, and A-2965 from the National Institutes of Health. Reported in part in abstract form in Circulation 1962, 26, 705.

$\dagger$ Work done during tenure of an Established Investigatorship of the American Heart Association. Career Scientist, Health Research Council of the City of New York, contract I-253.

\section{METHODS}

Animals. Male albino rats of the Carworth Farms Nelson (CFN) strain ${ }^{1}$ were used in all experiments except those involving parabiotic animals. In the latter instance, males and females obtained by inbreeding CFN rats or Wistar rats ${ }^{2}$ were used.

Dict. Rats were given water and food at will. The diet was either Purina rat chow (regular diet) or ground Purina chow with added $0.5 \%$ thiouracil, $4 \%$ cholesterol, and $1 \%$ cholic acid ${ }^{3}$ (TCC diet). The TCC diet was prepared by mixing a solution of cholesterol in ether with the ground chow, allowing the ether to evaporate, and blending cholic acid and thiouracil with the dry diet in a power mixer.

Induction of hypertension. Hypertension was induced by the method of Wilson and Byrom (3). The left renal arteries of rats weighing about $150 \mathrm{~g}$ were constricted by the application of a silver clip of $0.23 \mathrm{~mm}$ i.d. The right kidneys were left intact. Rats with sustained systolic blood pressures greater than $150 \mathrm{~mm} \mathrm{Hg}$ were considered hypertensive. As normotensive controls, rats with systolic blood pressures less than $125 \mathrm{~mm} \mathrm{Hg}$ were used. These were either intact or sham-operated.

Measurement of blood pressure. Systolic blood pressures were measured regularly, at intervals of 2 or 3 weeks, in the tail of the anesthetized rat in a warm room. A Gaertner cuff $22 \mathrm{~mm}$ long and an "Infraton" ${ }^{4}$ pickup were used.

Parabiotic pairs. Wistar rats were inbred in this laboratory by mating siblings for at least ten generations; CFN rats were inbred in the same way for three generations. Parabiotic pairs were prepared by suturing the previously divided lateral abdominal musculature of the two rats while maintaining separation of the peritoneal cavities and joining the scapulae.

Cholesterol concentration in serum. To obtain blood for the measurement of serum choiesterol levels at intervals, rats under light ether anesthesia were bled by

1 Carworth Farms, Inc., New York, N. Y.

2 Obtained from the Wistar Institute, Philadelphia, Pa.

3 Through the courtesy of the Ames Company, Inc., Elkhart, Ind.

4 Brecht-Bóuke, model E, Medical Electronics Development Co., Great Neck, N. Y. 
clipping the end of the tail. Otherwise, blood was obtained at sacrifice by bleeding from the left ventricle or the vessels of the neck. Blood was allowed to clot and then centrifuged. The colorimetric method of Zlatkis, Zak, and Boyle (4) was applied to the lipid extract of serum prepared by the method of Abell, Levy, Brodie, and Kendall (5).

Cholesterol concentration in the aorta. Rats were sacrificed by decapitation, or by exsanguination under ether anesthesia. The aorta was excised and cleaned of adherent fat, connective tissue, and most of the adventitia, while bathed in ice-cold saline. The sample of aorta used in all experiments included the arch and the descending thoracic aorta. The tissue was refluxed in $5 \%$ alcoholic $\mathrm{KOH}$ for three hours. The digest was diluted with an equal volume of water and the mixture extracted twice with 2 vol hexane. The hexane was evaporated to dryness, and the cholesterol in the residue was measured by means of the color reagent of Zlatkis and associates (4). This method was used because of its sensitivity, which permitted measurement of the cholesterol content of a single aorta. Preliminary experiments showed that this procedure gave somewhat higher absolute values (about $10 \%$ ) than the procedure of Sperry and Webb (6) but gave the same relative values for different samples.

Nitrogen. The nitrogen content of the aorta was used as a convenient reference basis for other measurements. To determine nitrogen, samples of tissue digests were subjected to Kjeldahl digestion, and the ammonia was measured by means of Nessler's reagent (7).

Cholesterol synthesis in the aorta in vitro. Rats were sacrificed by decapitation. The aorta was rapidly excised, dissected, as indicated in the previous section, and opened lengthwise. The incubation medium consisted of $2 \mathrm{ml}$ of Krebs-Ringer bicarbonate ( $\mathrm{pH} \mathrm{7.4)} \mathrm{containing}$
$30 \mu$ moles glucose and either acetate-1- $\mathrm{C}^{\mathbf{1 4}}$ or mevalonate$2-\mathrm{C}^{14}$. Three $\mu \mathrm{c}$ of acetate of SA $2 \mathrm{mc}$ per mmole, or 25 $\mu \mathrm{c}$ of acetate of SA $29 \mathrm{mc}$ per mmole, were used per flask. One $\mu \mathrm{c}$ of mevalonate of SA $1.4 \mathrm{mc}$ per mmole was used per flask. Incubations were carried out in an atmosphere of $95 \%$ oxygen and $5 \%$ carbon dioxide for 3 hours at $37^{\circ} \mathrm{C}$ in a Dubnoff metabolic shaker. Aortas of hypertensive and control animals were incubated simultaneously.

After incubation, $2 \mathrm{mg}$ of cholesterol (recrystallized 5 times from ethanol) was added to the flasks as carrier. The contents of the flasks were then saponified in $5 \%$ $\mathrm{KOH}$ in $80 \%$ ethanol (final concentration), and the cholesterol was extracted as described in the previous section. Cholesterol was isolated as the digitonide, which was dissolved by the procedure of Kabara (8), mixed with the phosphor solution $(0.4 \%$ 2,5-diphenyloxazole and $0.01 \%$ 1,4-bis-2-(5-phenyloxazolyl)-benzene in toluene) and counted in the Packard Tri-Carb liquid scintillation counter. The background was $15 \mathrm{cpm}$. Samples with low radioactivity were counted for the maximal period allowed in the Tri-Carb (100 minutes). The values given in the tables are means of at least four determinations on each sample.

In this laboratory, as in others $(9,10)$, it has been observed that the digitonide isolated after incubation of rat aorta with labeled precursors of cholesterol contains other labeled compounds in addition to cholesterol. The samples were therefore purified by passage through cholesterol dibromide. After the samples had been counted, $150 \mathrm{mg}$ of recrystallized cholesterol was added to each vial. The contents of the vials were evaporated to dryness, the digitonides were cleaved with pyridine, and the cholesterol was purified through the dibromide by the procedure of Fieser (11). In some experiments, bromination was repeated until the cholesterol reached con-
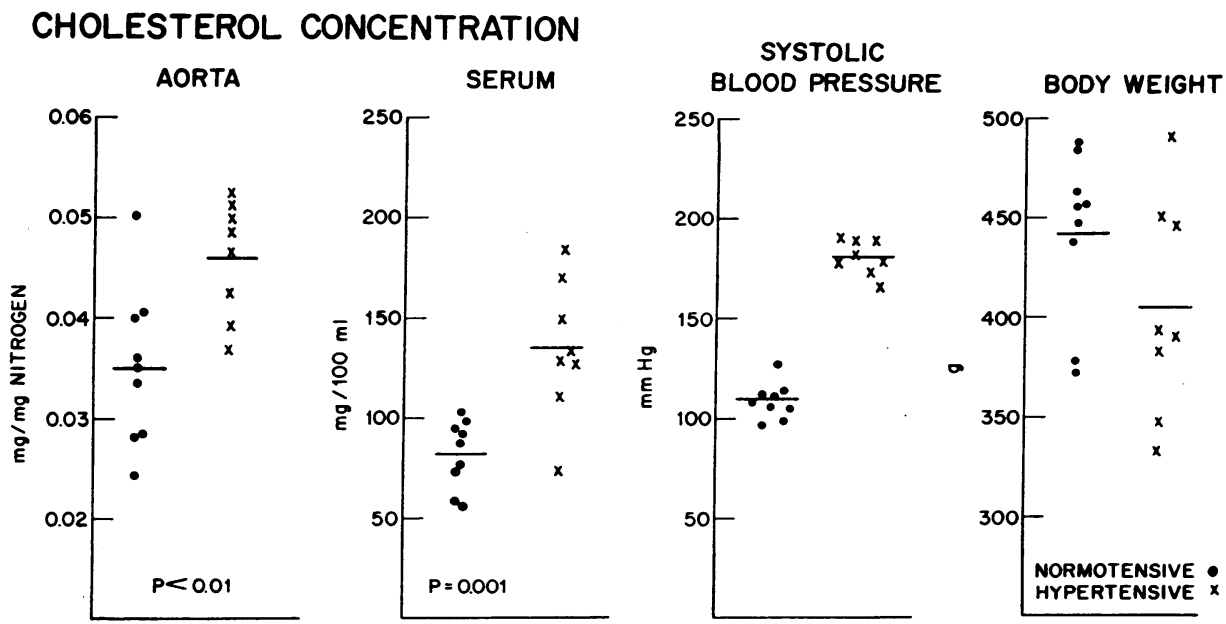

Fig. 1. Cholesterol concentration in AORTA AND SERUM OF NORMOTENSIVE AND HYPERTENSIVE RATS ON REGULAR DIET. Body weights and serum and aortic cholesterol concentrations are values at the time of sacrifice. Blood pressures are mean values for the period after operation. Each mark represents one rat. Horizontal lines indicate group means. 

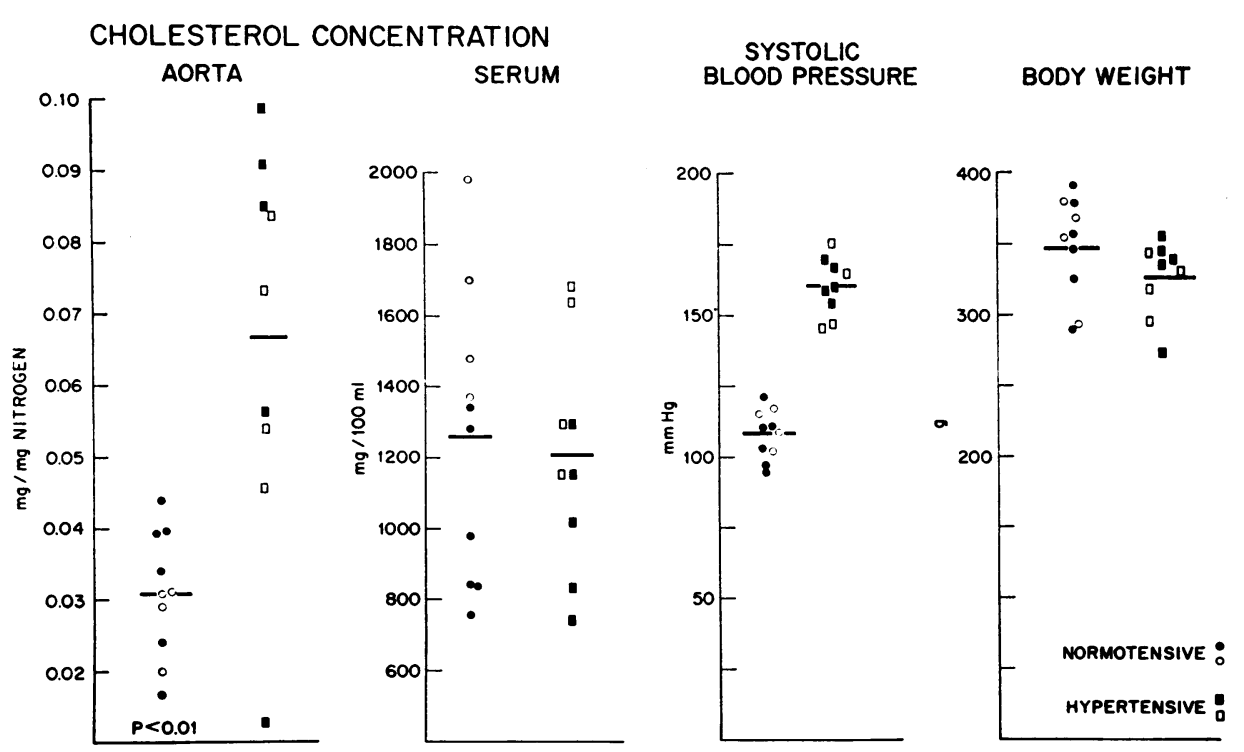

Fig. 2. Cholesterol concentration in aORTA AND SERUm OF NORMOtensive AND hyperTENSIVE RATS ON THE TCC DIET. Rats designated by the open marks had been on the TCC diet continuously for 3 months; those designated by the closed marks had been on TCC diet alternating with regular diet at intervals of 2 weeks for 14 weeks. Horizontal lines indicate group means. Blood pressures and serum cholesterol levels are mean values for the 14-week period. Aortic cholesterol concentrations and body weights are values at the time of sacrifice.

stant specific activity. In order to obtain enough labeled material for the purification, aortas of two or more rats were pooled after incubation in most experiments. In those experiments in which acetate of the higher specific activity was used, material from one rat was adequate.

\section{RESULTS}

Cholesterol concentration in the aorta. Experiment $I$. In Figure 1 are shown the values for cholesterol concentrations in sera and aortas of 9 normotensive and 8 hypertensive CFN rats maintained on the regular diet. The hypertensive rats had sustained systolic blood pressures above 150 $\mathrm{mm} \mathrm{Hg}$ for 3 months. The values in the figure are the mean blood pressures for this period. Serum cholesterol levels were measured at sacrifice only. The mean values for serum cholesterol were 82 $\mathrm{mg}$ per $100 \mathrm{ml}$ (range 58 to 103 , SE 6 ) for the normotensive and $135 \mathrm{mg}$ per $100 \mathrm{ml}$ (range 74 to $184, \mathrm{SE} 12)$ for the hypertensive rats $(\mathrm{p}=0.001)$. The mean values for aortic cholesterol concentration were $0.0352 \mathrm{mg}$ per $\mathrm{mg}$ aorta nitrogen (range 0.0243 to 0.0502 , SE 0.0028 ) for the normotensive and 0.0459 (range 0.0369 to $0.0523, \mathrm{SE}$ $0.0020)$ for the hypertensive rats $(p<0.01)$. Both serum and aortic cholesterol concentrations were higher in the hypertensive than in the control group. The data showing that hypertensive rats maintained on an unsupplemented chow diet develop higher serum cholesterol concentrations than control rats have not been reported previously. An abstract of work related to the mechanism of this effect of hypertension has been published (12).

Experiment II. In Figure 2 are shown cholesterol concentrations in sera and aortas of normotensive and hypertensive rats maintained on the TCC diet. Six out of the ten rats in the normotensive group and five out of the nine in the hypertensive group were given the TCC diet alternating with regular diet every 2 weeks for a total of 14 weeks. The remaining rats in both groups were on the TCC diet continuously for all 14 weeks. Since the subgroups were small, all normotensive and all hypertensive rats are combined in the figures, with rats on the alternating regimen designated by closed and those on the steady regimen by open marks. Serum cholesterol levels were measured every 2 weeks, and the mean values for the 14-week period are shown in Figure 2. The mean values for serum cholesterol 
TABLE I

Cholesterol concentration in serum and aorta of parabiotic pairs of rats*

\begin{tabular}{|c|c|c|c|c|c|c|}
\hline $\begin{array}{l}\text { Pair } \\
\text { no. }\end{array}$ & Rat & Sex & Strain & $\begin{array}{l}\text { Systolic } \\
\text { blood } \\
\text { pressure }\end{array}$ & $\begin{array}{c}\text { Serum } \\
\text { cholesterol }\end{array}$ & $\begin{array}{c}\text { Aortic } \\
\text { cholesterol }\end{array}$ \\
\hline 1 & $\begin{array}{l}\text { Clipped } \\
\text { Control }\end{array}$ & $\mathrm{F}$ & Wistar & $\begin{array}{c}m m H_{g} \\
141 \\
94\end{array}$ & $\begin{array}{c}m g / 100 m l \\
1,000 \\
888\end{array}$ & $\begin{array}{c}m g / m g \text { nitrogen } \\
0.0967 \\
0.0383\end{array}$ \\
\hline 2 & $\begin{array}{l}\text { Clipped } \\
\text { Control }\end{array}$ & $F$ & Wistar & $\begin{array}{l}160 \\
112\end{array}$ & $\begin{array}{l}871 \\
873\end{array}$ & $\begin{array}{l}0.0898 \\
0.0333\end{array}$ \\
\hline $3 \dagger$ & $\begin{array}{l}\text { Clipped } \\
\text { Control }\end{array}$ & $\mathrm{M}$ & Wistar & $\begin{array}{l}158 \\
108\end{array}$ & $\begin{array}{l}674 \\
643\end{array}$ & $\begin{array}{l}0.0746 \\
0.0353\end{array}$ \\
\hline 4 & $\begin{array}{l}\text { Clipped } \\
\text { Control }\end{array}$ & $\mathrm{F}$ & $\mathrm{CFN}$ & $\begin{array}{l}150 \\
112\end{array}$ & $\begin{array}{l}1,209 \\
1,028\end{array}$ & $\begin{array}{l}0.135 \\
0.0522\end{array}$ \\
\hline 5 & $\begin{array}{l}\text { Clipped } \\
\text { Control }\end{array}$ & $\mathrm{F}$ & CFN & $\begin{array}{l}142 \\
105\end{array}$ & $\begin{array}{l}1,154 \\
1,047\end{array}$ & $\begin{array}{l}0.0997 \\
0.0354\end{array}$ \\
\hline 6 & $\begin{array}{l}\text { Clipped } \\
\text { Control }\end{array}$ & $\mathbf{M}$ & Wistar & $\begin{array}{r}114 \\
92\end{array}$ & $\begin{array}{l}663 \\
682\end{array}$ & $\begin{array}{l}0.0358 \\
0.0318\end{array}$ \\
\hline 7 & $\begin{array}{l}\text { Clipped } \\
\text { Control }\end{array}$ & $\mathbf{M}$ & Wistar & $\begin{array}{l}111 \\
101\end{array}$ & $\begin{array}{l}493 \\
482\end{array}$ & $\begin{array}{l}0.0332 \\
0.0222\end{array}$ \\
\hline
\end{tabular}

* Blood pressures and serum cholesterol levels are the mean values for the period on the TCC diet. Serum cholesterol concentrations were comparable in members of a pair; aorta cholesterol concentrations were higher in the rat with the higher blood pressure.

$\dagger$ This pair of animals was loosely joined. They remained united for two months, came apart, and remained separated for 2 months before sacrifice.

concentration were $1,257 \mathrm{mg}$ per $100 \mathrm{ml}$ (range 754 to 1,985 , SE 129) for the normotensive and $1,206 \mathrm{mg}$ per $100 \mathrm{ml}$ (range 742 to $1,681, \mathrm{SE}$ 106) for the hypertensive rats. The mean values for aortic cholesterol concentration were 0.0308 $\mathrm{mg}$ per $\mathrm{mg}$ tissue nitrogen (range 0.0168 to 0.0440 , SE 0.0028) for the normotensive and $0.0668 \mathrm{mg}$ per $\mathrm{mg}$ nitrogen (range 0.0129 to $0.0987, \mathrm{SE}$ 0.0096) for the hypertensive rats. Although there was no significant difference in mean serum cholesterol level between the two groups, the mean aortic cholesterol concentration was twice as high in the hypertensive group $(p<0.01)$.

At no time in the experimental period did the hypertensive rats show significantly higher serum cholesterol levels than their normotensive controls. This result appears to be characteristic of hypertensive CFN rats maintained on the atherogenic diet, and contrasts with the results previously obtained with hypertensive Wistar rats, which developed higher serum cholesterol levels than normotensive controls when fed the TCC diet (13).

Experiment III. Floyer and Richardson have shown that it is possible to maintain parabiotic pairs of rats in which the rat with a clip on one renal artery has a higher blood pressure than the intact rat (14). In experiment III, similar rats were used. A clip was placed on the left renal artery of one, which was then united with his normal control. One and one-half to 4 months later, the rats were placed on the TCC diet for an additional 3 to 4 months. Serum cholesterol levels and blood pressures were measured at intervals of 2 to 3 weeks. The mean values for the blood pressures and serum cholesterol levels of each rat for the period on the diet and the aortic cholesterol concentrations are shown in Table I. Serum cholesterol levels were not significantly different in members of a pair. In pairs 1 through 5 , the blood pressures of the two rats differed significantly ( 37 to $50 \mathrm{~mm} \mathrm{Hg}$ ), and the cholesterol concentration in the aorta of the rat with higher blood pressure was two to three times higher than in the control rat. In pairs 6 and 7, there was a smaller difference in blood pressure (10 or $20 \mathrm{~mm} \mathrm{Hg}$ ) and in aortic cholesterol concentration (10 or $50 \%$ ) between the clipped and control rat.

Cholesterol synthesis in the aorta in vitro. For studies of the incorporation of labeled precursors into cholesterol, rats that had been hypertensive for 2 to 4 months and normotensive controls were used. All were maintained on the regular diet. Table II shows the results of 9 experiments in 
TABLE II

Synthesis of cholesterol from acetate-1-C $C^{14}$ by rat aorta in vitro

\begin{tabular}{|c|c|c|c|c|c|c|c|}
\hline \multirow{2}{*}{$\begin{array}{l}\text { Exp't } \\
\text { no. }\end{array}$} & \multirow[b]{2}{*}{ Rats* } & \multirow{2}{*}{$\begin{array}{c}\text { cpm } \\
\text { before } \\
\text { bromination }\end{array}$} & \multicolumn{3}{|c|}{$\mathrm{cpm}$ after bromination } & \multirow{2}{*}{$\begin{array}{c}\mathrm{cpm} / \\
\text { aorta }\end{array}$} & \multirow{2}{*}{$\underset{\mathrm{cpm} /}{\mathrm{cpm} /}$} \\
\hline & & & I & II & III & & \\
\hline 1 & $\begin{array}{l}\text { I (5) } \\
\mathrm{H}(5)\end{array}$ & $\begin{array}{r}16 \\
117\end{array}$ & $\begin{array}{r}9 \\
79\end{array}$ & $\begin{array}{l}10 \\
69\end{array}$ & $\begin{array}{r}8 \\
72\end{array}$ & $\begin{array}{r}1.6 \\
14.4\end{array}$ & $\begin{array}{l}0.8 \\
4.9\end{array}$ \\
\hline 2 & $\begin{array}{l}\mathrm{N}(2) \\
\mathrm{H}(2)\end{array}$ & $\begin{array}{r}23 \\
529\end{array}$ & $\begin{array}{r}5 \\
100\end{array}$ & $\begin{array}{r}6 \\
83\end{array}$ & & $\begin{array}{c}3 \\
41.5\end{array}$ & $\begin{array}{r}1.3 \\
13.5\end{array}$ \\
\hline 3 & $\begin{array}{l}\text { i (4) } \\
\mathrm{H}(3)\end{array}$ & $\begin{array}{l}20 \\
75\end{array}$ & $\begin{array}{l}27 \\
60\end{array}$ & & & $\begin{array}{l}6.8 \\
20\end{array}$ & $\begin{array}{l}4.7 \\
9.5\end{array}$ \\
\hline 4 & $\begin{array}{l}\mathrm{N}(1) \dagger \\
\mathrm{H}(1) \dagger\end{array}$ & $\begin{array}{r}88 \\
312\end{array}$ & $\begin{array}{l}15 \\
87\end{array}$ & $\begin{array}{l}14 \\
20\end{array}$ & 21 & $\begin{array}{l}14 \\
21\end{array}$ & $\begin{array}{l}6.7 \\
7.2\end{array}$ \\
\hline 5 & $\begin{array}{l}\mathrm{N}(1) \dagger \\
\mathrm{H}(1) \dagger\end{array}$ & $\begin{array}{l}129 \\
674\end{array}$ & $\begin{array}{r}26 \\
147\end{array}$ & $\begin{array}{r}6 \\
56\end{array}$ & $\begin{array}{r}5 \\
53\end{array}$ & $\begin{array}{r}5 \\
53\end{array}$ & $\begin{array}{r}2.6 \\
27.2\end{array}$ \\
\hline 6 & $\begin{array}{l}\mathrm{N}(1) \dagger \\
\mathrm{H}(1) \dagger\end{array}$ & $\begin{array}{r}64 \\
1,610\end{array}$ & $\begin{array}{r}56 \\
340\end{array}$ & $\begin{array}{r}47 \\
182\end{array}$ & 157 & $\begin{array}{r}47 \\
157\end{array}$ & $\begin{array}{l}21.0 \\
53.0\end{array}$ \\
\hline 7 & $\begin{array}{l}\mathrm{N}(1) \dagger \\
\mathrm{H}(1) \dagger\end{array}$ & $\begin{array}{r}58 \\
880\end{array}$ & $\begin{array}{r}8 \\
116\end{array}$ & & & $\begin{array}{r}8 \\
116\end{array}$ & $\begin{array}{r}2.6 \\
39.5\end{array}$ \\
\hline 8 & $\begin{array}{l}\mathrm{N}(1) \dagger \\
\mathrm{H}(1) \dagger\end{array}$ & $\begin{array}{r}32 \\
2,646\end{array}$ & $\begin{array}{r}7 \\
467\end{array}$ & $\begin{array}{r}3 \\
353\end{array}$ & 300 & $\begin{array}{r}3 \\
300\end{array}$ & $101^{1.6}$ \\
\hline 9 & $\begin{array}{l}X(1) \dagger \\
\mathrm{H}(1) \dagger\end{array}$ & $\begin{array}{r}42 \\
1,089\end{array}$ & $\begin{array}{r}7 \\
203\end{array}$ & $\begin{array}{r}3 \\
170\end{array}$ & 200 & $\begin{array}{r}3 \\
200\end{array}$ & $\begin{array}{r}1.3 \\
68.2\end{array}$ \\
\hline
\end{tabular}

${ }^{*} \mathrm{~N}=$ normotensive, $\mathrm{H}=$ hypertensive. The numbers in parentheses indicate the number of aortas used in each experiment.

$t$ In these experiments, acetate of the higher specific activity was used.

$\ddagger$ These values were calculated from the counts remaining after the last bromination.

The difference in incorporation of acetate to cholesterol between normotensive and hypertensive rats is significant with an upper binominal confidence limit of $44.5 \%(p=.005)$.

which acetate was used as the precursor. The counts per minute in cholesterol digitonide are presented together with the yield after each passage of cholesterol through the dibromide. The incorporation of acetate into cholesterol, whether expressed as counts per minute per aorta, or as counts per minute per milligram aorta nitrogen, was higher in aortas of hypertensive rats. The average increase in incorporation was 24-fold when calculated per aorta and 18-fold when cal-

TABLE III

Synthesis of cholesterol from mevalonate-2-C $C^{14}$ by rat aorta in vitro*

\begin{tabular}{|c|c|c|c|c|c|c|c|c|}
\hline \multirow{2}{*}{$\begin{array}{l}\text { Exp't } \\
\text { no. }\end{array}$} & \multirow[b]{2}{*}{ Rats } & \multirow{2}{*}{$\begin{array}{c}\text { cpm } \\
\text { before } \\
\text { bromination }\end{array}$} & \multicolumn{4}{|c|}{ cpm after bromination } & \multirow{2}{*}{$\begin{array}{l}\text { cpm/ } \\
\text { aortat }\end{array}$} & \multirow{2}{*}{$\begin{array}{c}\text { cpm / } \\
\text { mg nitrogent }\end{array}$} \\
\hline & & & I & II & III & IV & & \\
\hline 1 & $\begin{array}{l}\mathrm{N}(3) \\
\mathrm{H}(3)\end{array}$ & $\begin{array}{r}19 \\
330\end{array}$ & $\begin{array}{r}3 \\
61\end{array}$ & $\begin{array}{r}2 \\
41\end{array}$ & 52 & 43 & $\begin{array}{r}0.7 \\
14.3\end{array}$ & $\begin{array}{l}0.3 \\
4.2\end{array}$ \\
\hline 2 & $\begin{array}{l}\mathrm{N}(2) \\
\mathrm{H}(2)\end{array}$ & $\begin{array}{r}23 \\
236\end{array}$ & $\begin{array}{r}9 \\
34\end{array}$ & $\begin{array}{r}\text { NS } \\
29\end{array}$ & 37 & & $\begin{array}{l}\text { NS } \\
18.5\end{array}$ & $\begin{array}{l}\text { NS } \\
6.3\end{array}$ \\
\hline 3 & $\begin{array}{l}\mathrm{N}(4) \\
\mathrm{H}(4)\end{array}$ & $\begin{array}{r}64 \\
351\end{array}$ & $\begin{array}{r}9 \\
19\end{array}$ & $\begin{array}{r}\mathrm{NS} \\
2\end{array}$ & & & $\begin{array}{l}\mathrm{NS} \\
0.5\end{array}$ & $\begin{array}{l}\text { NS } \\
0.15\end{array}$ \\
\hline 4 & $\begin{array}{l}\mathrm{N}(4) \\
\mathrm{H}(2)\end{array}$ & $\begin{array}{l}25 \\
61\end{array}$ & $\begin{array}{l}5 \\
7\end{array}$ & $\begin{array}{r}\mathrm{NS} \\
4\end{array}$ & & & $\begin{array}{c}\text { NS } \\
2\end{array}$ & $\begin{array}{l}\text { NS } \\
0.7\end{array}$ \\
\hline 5 & $\begin{array}{l}\mathrm{N}(4) \\
\mathrm{H}(4)\end{array}$ & $\begin{array}{r}40 \\
187\end{array}$ & $\begin{array}{l}27 \\
64\end{array}$ & $\begin{array}{l}21 \\
31\end{array}$ & & & $\begin{array}{l}5.3 \\
7.8\end{array}$ & $\begin{array}{l}2.3 \\
2.6\end{array}$ \\
\hline 6 & $\begin{array}{l}\mathrm{N}(4) \\
\mathrm{H}(4)\end{array}$ & $\begin{array}{r}132 \\
1,404\end{array}$ & $\begin{array}{l}14 \\
90\end{array}$ & $\begin{array}{r}5 \\
19\end{array}$ & $\begin{array}{r}5 \\
19\end{array}$ & & $\begin{array}{l}1.3 \\
4.8\end{array}$ & $\begin{array}{l}0.6 \\
1.8\end{array}$ \\
\hline
\end{tabular}

* $\mathrm{N}=$ normotensive, $\mathrm{H}=$ hypertensive, $\mathrm{NS}=\mathrm{cpm}$ not significantly above background. Numbers in parentheses refer to the number of aortas used in each experiment.

The difference in incorporation of mevalonate to cholesterol in aortas of normotensive and hypertensive rats is significant with an upper binomial confidence limit of $45.9 \%(p=.025)$.

$\dagger$ These values were calculated from the counts remaining after the last bromination. 
culated per milligram aorta nitrogen. The difference in incorporation is greater when calculated per aorta because the aortas of hypertensive rats were, on the average, $40 \%$ larger than those of controls, as a consequence of medial hypertrophy.

Table III shows the results of six experiments in which mevalonate was used as the precursor. Although some of the samples obtained after incubation of aortas of normotensive rats are so low in activity that they are not significantly above the background, the incorporation of mevalonate into cholesterol is higher in aortas of hypertensive rats in each experiment.

\section{DISCUSSION}

These experiments have shown that hypertensive rats develop higher aortic cholesterol concentrations than normotensive controls whether they are maintained on a regular chow diet or on a diet of chow with added thiouracil, cholesterol, and cholic acid (TCC diet). A previous report showed that rats will develop atherosclerotic lesions when maintained on the latter diet (13), but in the present study, rats were sacrificed before they had developed gross atherosclerotic lesions in the aorta.

When the rats were maintained on the regular diet, hypertensive ones had higher cholesterol concentrations in both serum and the aorta than normotensive controls. Since there is evidence for the transfer of plasma cholesterol to arterial walls $(15,16)$, these changes in aortic cholesterol concentration might be attributed to an influence of the plasma cholesterol concentration. When the rats were maintained on the TCC diet, however, the mean serum cholesterol levels were not significantly different in the hypertensive and normotensive groups, but the mean aortic cholesterol concentration was significantly higher in the hypertensive group. In parabiotic pairs of rats in which the blood pressures of the two rats differed but the serum cholesterol levels were comparable, the aortic cholesterol concentration in the rat with the higher blood pressure was higher than in the rat with the lower blood pressure. The difference between aortic cholesterol concentration in normotensive and hypertensive rats is, therefore, not dependent on a difference in serum cholesterol levels.
Furthermore, the findings in parabiotic rats suggest that the difference in aortic cholesterol concentration is independent of the concentration of any blood component, with the possible exception of components with relatively short turnover times in blood. Parabiotic rats such as those used in the present experiments have a common circulation and an exchange of blood between rats with a half-time of about 1 hour (17).

Evidence that aortic cholesterol concentrations in normotensive rats are not readily affected by serum cholesterol levels is given by the findings in rats maintained on different diets (Figures 1 and 2). These rats showed no increase in aortic cholesterol concentration on the TCC diet, as compared with the regular diet, in spite of 15 -fold difference in serum cholesterol levels on the two regimens. It is, of course, possible that they would have had higher aortic cholesterol concentrations after a longer period on the TCC diet, since none of them had developed gross atherosclerotic lesions in the aorta up to the time of sacrifice.

The increase in aortic cholesterol concentration in rats with high blood pressure appears to be mediated through local factors operating in or on the vessel wall rather than through an elevation of serum cholesterol levels. One of the local factors may be an effect of the high blood pressure on the movement of cholesterol between plasma and vessel wall, which results in a net transfer of cholesterol to the vessel. Such an effect may account for the observation that hypertensive rats had aortic cholesterol concentrations that were $50 \%$ higher when they were maintained on the TCC diet than when they were maintained on the regular diet (Figures 1 and 2). Their serum cholesterol concentrations were 10 times higher on the TCC diet. If the high blood pressure increases the rate of transfer of cholesterol from plasma to vessel, it may have a more pronounced effect on aortic cholesterol concentration at higher plasma cholesterol concentrations.

The possibility that cholesterol synthesis in the aorta wall may constitute another local factor affecting aortic cholesterol concentration was also considered in the present studies. Measurements of the incorporation of labeled precursors into cholesterol in vitro by aortas of rats on the regular diet indicated that aortas of hypertensive rats 
have a greater capacity to synthesize cholesterol than those of controls. The results suggest that synthesis of cholesterol in the aorta may contribute to the increased aortic cholesterol concentration in hypertensive rats. Further work is needed to establish the quantitative importance of local synthesis of cholesterol in the aortas of hypertensive rats relative to the other factors that may influence aortic cholesterol concentration.

We recognize that the increased rate of cholesterol synthesis may be a concomitant of medial hypertrophy. Aortas of the hypertensive rats used in this study had undergone considerable hypertrophy, but we do not know whether the rate of growth was greatly above normal at the time the samples were taken. An increased rate of growth may require an acceleration of the rate of synthesis of cholesterol as well as other substances needed for the formation of new tissue. The aorta preparations used in the present work consisted of media, intima, and part of the adventitia. The identification of the particular layers of the vessel wall involved in the increase in rate of aortic cholesterol synthesis in hypertensive rats may indicate whether this change is related to medial hypertrophy.

\section{SUM MARY}

Aortic cholesterol concentrations were found to be higher in hypertensive rats than in normotensive controls. These differences were observed whether the serum cholesterol concentrations in the hypertensive rats were higher than or comparable to the levels in control rats. The rate of synthesis of cholesterol in vitro was found to be higher in aortas of hypertensive rats than in those of controls. The results suggest that the difference between aortic cholesterol concentrations in normotensive and hypertensive rats is dependent on local effects of the high blood pressure on the aorta, on changes in the rate of cholesterol synthesis in the vessel, or both, rather than on a change in serum cholesterol concentration.

\section{REFERENCES}

1. Pickering, G. W. High Blood Pressure. New York, Grune \& Stratton, 1955, p. 231.

2. Page, I. H. Atherosclerosis. An introduction. Circulation 1954, 10, 1.
3. Wilson, C., and F. B. Byrom. The vicious circle in chronic Bright's disease. Experimental evidence from the hypertensive rat. Quart. J. Med. 1941, $10,65$.

4. Zlatkis, A., B. Zak, and A. J. Boyle. A new method for the direct determination of serum cholesterol. J. Lab. clin. Med. 1953, 41, 486.

5. Abell, L. L., B. B. Levy, B. B. Brodie, and F. E. Kendall. A simplified method for the estimation of total cholesterol in serum and demonstration of its specificity. J. biol. Chem. 1952, 195, 357.

6. Sperry, W. M., and M. Webb. A revision of the Schoenheimer-Sperry method for cholesterol determination. J. biol. Chem. 1950, 187, 97.

7. Koch, F. C., and T. L. McMeekin. A new direct Nesslerization micro-Kjeldahl method and a modification of the Nessler-Folin reagent for ammonia. J. Amer. chem. Soc. 1924, 46, 2066.

8. Kabara, J. J. A quantitative micromethod for the isolation and liquid scintillation assay of radioactive free and ester cholesterol. J. Lab. clin. Med. 1957, 50, 146.

9. Dayton, S., S. Hashimoto, and J. Jessamy. Cholesterol kinetics in the normal rat aorta, and the influence of different types of dietary fat. J. Atheroscler. Res. 1961, 1, 444.

10. Foster, D. W., and M. D. Siperstein. Effect of diabetes on cholesterol and fatty acid synthesis in the rat aorta. Amer. J. Physiol. 1960, 198, 25.

11. Fieser, L. F. Cholesterol and companions. VII. Steroid dibromides. J. Amer. chem. Soc. 1953, 75, 5421.

12. Adel, H. N., M. M. Daly, Q. B. Deming, L. Brun, and V. Raeff. Effect of hypertension on cholesterol synthesis in the rat (abstract). Circulation 1962, 26, 681.

13. Deming, Q. B., E. H. Mosbach, M. Bevans, M. M. Daly, L. L. Abell, E. Martin, L. M. Brun, E. Halpern, and R. Kaplan. Blood pressure, cholesterol content of serum and tissues and atherogenesis in the rat. The effect of variations in blood pressure on the cholesterol content of serum and tissues and on the development of atherosclerosis in rats on a high cholesterol diet. J. exp. Med. 1958, 107, 581.

14. Floyer, M. A., and P. C. Richardson. Mechanism of arterial hypertension. Role of capacity and resistance vessels. Lancet 1961, 1, 253.

15. Duncan, L. E., Jr., and K. Buck. Passage of labeled cholesterol into the aortic wall of the normal dog. Circulat. Res. 1959, 7, 765.

16. Newman, H. A. I., and D. B. Zilversmit. Quantitative aspects of cholesterol flux in rabbit atheromatous lesions. J. biol. Chem. 1962, 237, 2078.

17. Huff, R. L., R. Trautman, and D. C. Van Dyke. Nature of exchange in parabiotic rats. Amer. J. Physiol. 1950, 161, 56. 